\title{
Risk Factors in Derivatives Markets
}

\author{
Raimonda Martinkutè-Kaulienè
}

\begin{abstract}
A B S T R A C T
Objective: The objective of the article is to analyse and present the classification of risks actual to derivative securities.

Research Design \& Methods: The analysis is based on classical and modern literature findings and analysis of newest statistical data.

Findings: Despite their purpose to hedge from risks, derivative contracts are risky as every financial activity in the market. The analysis led to the conclusion, that the main risks typical for derivatives contracts and their traders are market risk, liquidity risk, credit and counterparty risk, legal risk and transactions risk. Pricing risk and systemic risk is also quite important. The analysis showed that market risk is the most important kind of risk that in many situations influences the level of remaining risks. Market risk occurs when the investor misjudges the market direction, counterparty risk occurs when misjudgement refers to the business partner. Some risks exist despite the employment of derivatives.

Implications \& Recommendations: It was suggested that risk of derivative contracts can be related with the following factors: main characteristics of contracts; trading conditions; position assumed in the contract; complexity of the contract.
\end{abstract}

Contribution \& Value Added: The originality of this work lies in studying various aspects of risk factors influencing the risks of derivative securities and suggested classification of these factors

\begin{tabular}{ll}
\hline Article type: & research paper \\
Keywords: & risk; factor; derivative security; option contract; forward; future \\
JEL codes: & G10, G23
\end{tabular}

Received: 7 September $2014 \quad$ Revised: 12 November $2014 \quad$ Accepted: 2 December 2014

\section{Suggested citation:}

Martinkutè-Kaulienè, R. (2014). Risk Factors in Derivatives Markets. Entrepreneurial Business and Economics Review, 2(4), 71-83, DOI: http://dx.doi.org/10.15678/EBER.2014.020405. 


\section{INTRODUCTION}

Over the last years market conditions and environment for business have dramatically changed. Modern information technologies allowed market participants to create complex individual financial transactions and various portfolios. Because of the huge amounts of events, news and financial information, the behaviour of financial markets participants becomes also more complex.

As financial markets become uncertain and risky, measuring and managing the risks of participants in the financial markets became the main focus of modern finance theory. Financial engineers started to create financial instruments to manage the increasing risks. Changing conditions in the financial markets such as fluctuating exchange rates, interest rates, stock prices, commodity prices were ideal circumstances for the development of derivatives markets. An infinite number of derivative products were created. Their values depend on the value of one or more underlying assets or indices of asset values. Simple futures contracts in foreign exchange, Eurodollars, and bonds evolved into complex swaps and swaptions, strips and straps, caps and floors and other investment strategies whose purpose is to manage financial risk. As many authors state, the introduction of derivatives started a revolution in finance and changed the face of finance by creating new ways to understand, measure and manage risk (Scalcone, 2011). The main reason of the success of derivatives was their ability to relocate the risk. Also they left the possibility to get speculative and arbitrage profit. At the moment the size of derivatives markets is enormous as is their role in both risk management and as a source of risk (The Global derivatives market, 2014). Market participants together with new possibilities to invest and to hedge risks, are exposed to new kinds of risk.

As the statistics shows, some derivatives are highly complex but others are quite simple. The main condition of the successful use of the derivative contracts is understanding, evaluation and management of their riskiness. It is important to compare the necessities and possible dangers of derivatives in order to choose the proper derivative and to manage its risk.

The subject of the research is risk factors affecting derivatives. The purpose of the article is to analyse and present the classification of risks actual to derivative securities. In order to achieve the purpose of the article, some tasks were fulfilled: theoretical analysis of derivatives was made, changes in the derivative markets were evaluated, benefits and risks of derivatives were distinguished and analysed, conclusions and suggestions were made. Analytical-systemic analysis of scientific literature, comparative analysis and graphical modelling were used for the research.

\section{LITERATURE REVIEW}

Derivatives are substantially different from standard securities. Various authors describe a derivative security quite similarly (Hull, 2000; Benhamou, 2007; Culp, 2004). The Oxford dictionary defines a derivative as something derived or obtained from another, coming from a source; not original (Chisholm, 2004). In the field of financial economics, a derivative security is generally referred to a financial contract whose value is derived from the value of an underlying asset. 
A derivative is a contract between a buyer and a seller entered today into a transaction to be fulfilled at a future point in time. The value of this transaction depends on the value of more basic variables such as stock prices, commodity prices, index levels, interest rates, or/and exchange rates (Rangarajan, 2012). Thus derivatives are financial instruments which payoffs derive from other, primary underlying financial variables (Benhamou, 2007). There are a wide range of financial assets that have been used as underlying, including equities or equity index, fixed-income instruments, foreign currencies, commodities, credit events and even other derivative securities. Depending on the types of underlying, the values of the derivative contracts can be derived from the corresponding equity prices, interest rates, exchange rates, commodity prices and the probabilities of certain credit events (Culp, 2004).

The main categories of derivatives are forward and futures contracts, options and swaps. They are financial instruments that are mainly used to protect against and manage risks, and very often also serve as arbitrage or investment purposes, providing various advantages compared to securities (Benhamou, 2007).

Theoretical description of separate derivatives is widely examined and can be found in works of many authors (Hull, 2000; Benhamou, 2007; Culp, 2004; Sill, 1997; Kolb et al., 2010), but in order to analyse benefits and risks of derivatives it is worth to look through them once again.

A forward contract is an agreement made directly between two parties. One party agrees to buy a commodity or a financial asset on a date in the future at a fixed price. The other party agrees to deliver that commodity or asset at the predetermined price (Hull, 2000). Both sides are obliged to fulfil the conditions of the contract, regardless the value of the commodity or asset at the moment of delivery. Because forwards are an agreement between two parties, the contract terms and conditions can be customized. This convenience can present a source of risk because of the default of one party obligations.

A futures contract is similar to a forward contract. One party in the contract agrees to deliver a commodity or asset on a future date at a fixed price and the other party agrees to take the delivery. The main difference is that the deal is made through an organized and regulated exchange, not directly between two parties. So future contracts are somewhat protected against default risk.

Swaps are agreements between two parties to exchange one series of future cash flows for another. Underlying assets on swaps can be different. An example of swap could be borrowing money from the bank at a variable rate and entering into the swap contract to fix costs of funding (Kolb et al., 2010). Swaps are over-the-counter contracts. Swaps are used to manage or hedge the risks associated with volatile interest rates, currency exchange rates, commodity prices and share prices.

The last group of derivatives is option contracts. A call option gives the holder the right to buy an underlying asset by a certain date at a fixed price. A put option conveys the right to sell an underlying asset by a certain date at a fixed price. The purchaser of an option has to pay an initial sum of money (referred to as the premium to the seller or as writer of the contract), because the option provides flexibility and the right to choose. Options can be negotiated between two parties in the OTC market or can be freely traded on organized exchanges, for example, EUREX Traded options are generally 
standardized products, though some exchanges have introduced contracts with some features that can be customized (Chisholm, 2004).

Number of types of OTC derivatives is limited only by the creativity of their users. Over-the counter derivatives can be customized according to the need of both parties involved.

According to Kotze (2011) and other authors (Krawietz, 1998; Munter \& Rotcliffe, 2001) two types of traders exist in derivative markets: speculators and hedgers. Hedges and speculators have different needs in the market, but derivatives are attractive financial products for both of them. For speculators derivatives are a way to expose their portfolio to some market risk with a view to outperform the market. Derivatives are an alternative to investing directly in assets without buying and holding the asset itself (The Global Derivatives Market, 2014). They also allow investments into underlying and risks that cannot be purchased directly (credit derivatives or weather derivatives). Investors can take positions in the market if they expect the underlying asset to fall in value (Huang et al., 2001). Hedgers, on the other hand, allow investors to reduce market risk to which they are already exposed to (Kotze, 2011).

Derivatives make future risks and object of trade. For example, enterprises use derivatives to protect themselves against changes in interest rates, raw material prices, exchange rates and so on. For example, if a firm regularly needs a particular commodity, such as petroleum, then it can guard against a rise in the price of oil by purchasing a call option. If the price of oil remains low, then the option is not exercised and the oil is bought at the current price in the market, while if the price rises above the strike, then the option is exercised to buy oil at a below-market value (Pineda \& Conejo, 2012). Derivatives serve as insurance against unwanted price movements and reduce the volatility of companies' cash flows, which in turn results in more reliable forecasting, lower capital requirements, and higher capital productivity (The Global Derivatives Market, 2014; Cusatis \& Thomas, 2005).

As Scalcione states (2011), derivatives allow for the most efficient and cost effective risk fractioning. For the first time derivatives have allowed risk taking on a virtually unlimited spectrum of products and services, on all measurable and identifiable risks that may exist in modern finance. The commoditisation of risk makes the sale of risk possible. Risk buyers effectively take on financial exposure to various types of risk while hedgers unload unwanted exposures. Such convenience helps to diversify risks and to reach greater economic efficiency and more efficient risk taking. Because of the use of derivatives, diversification of risk holding is less costly, more effective, and more available (Scalcione, 2011). Derivatives represent rapid, manageable tools to acquire and eliminate exposure to desired financial variables. In addition, derivatives allow domestic investors to acquire exposure to foreign markets without the necessity of dealing with foreign laws, foreign investments, and currency exchange (Scalcione, 2011).

It can be concluded that derivatives offer organisations the opportunity to divide financial risk into smaller parts and to trade those risks as commodity. They can be used to protect against specific exposure of a business or can be used by market participants to take on risk and speculate on the movement in the value of underlying assets without owning these assets. Derivatives can help organisations meet their specific risk 
management objectives, so it could be stated, that derivatives carry economic advantages for many business activities.

\section{RESULTS AND DISCUSSION}

If to look through the history, modern financial derivatives have been available for little more than a century, but the fundamental elements of derivative contracts have been available for millennia. Some parts of derivatives contracts have been already found in Babylon (1800 BC), in ancient Japan futures on rice were typically traded in 1740 (Scalcione, 2011). Elements of derivatives have also been found in ancient textbooks in Greece. The description of the first speculative strategy using elements of derivatives was introduced in the work of Aristotle. Origins of derivative contracts were analysed by many authors (Hung et al., 2011; Carruthers, 2013; Miffre \& Brooks, 2013). All of them emphasise that derivative securities from the beginning were originally used to hedge commodities products such as agricultural production and metals.

The modern history of derivatives began in the middle of 1800 s in the U.S. with the creation of the world's biggest commodity market in Chicago and the introduction of the first futures contracts traded on commodities. Since then, the diffusion of derivatives has been unstoppable and the derivatives market today has reached a size that is fascinating and terrifying at the same time (Scalcione, 2011).

According to statistics gathered by FIA from 84 exchanges worldwide, 21.64 billion futures and options contracts were traded in 2013, an increase of $2.1 \%$ from the previous year, but still well below the number of contracts traded in 2012 and 2011 (FIA, 2013).

Futures trading accounted for 12.22 billion contracts, just over $56 \%$ of total industry volume. Trading of options accounted for the other $44 \%$. By category, contracts based on equity indexes and individual stocks accounted for 11.77 billion, $54 \%$ of total volume. Interest rate futures and options accounted for 3.33 billion, $15 \%$ of total volume (Figure 1).

Figure 2 presents the key markets for derivatives traded on exchanges which are North America and Asia Pacific, then European markets follow. According data obtained from 84 exchanges worldwide, the biggest trading volumes are attributable to $\mathrm{CME}$ Group of exchanges and to Eurex.

Globalisation of financial markets enables derivatives trade is almost limitless. Main participants in the derivative markets are banks, investment firms, insurance companies and corporates, but individual investors can trade in these markets as well. There are two competing segments in the derivatives market: the off-exchange or over-thecounter (OTC) segment and the on-exchange segment (Hull, 2000; Benhamou, 2007)). Over-the counter derivatives are traded privately mostly among banks and their large corporate and institutional customers. Over-the counter market is much bigger than exchange traded market, but OTC market lacks some protective elements, such as margin deposits, price limits, daily value adjustments and guaranties of clearing house. Federal authorities can't control and regulate all OTC market contracts (Benhamou, 2007). 


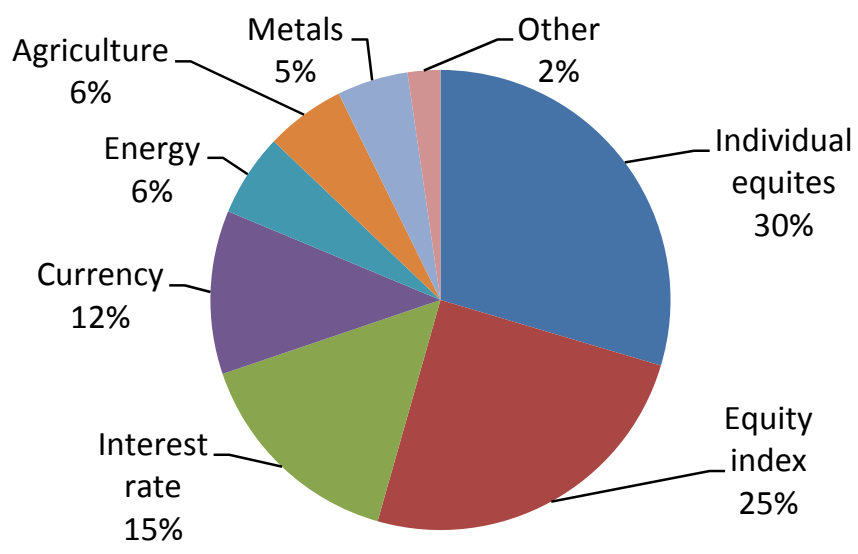

Figure 1. Global futures and options volume by category in 2012 source: FIA Annual Volume Survey 2013.

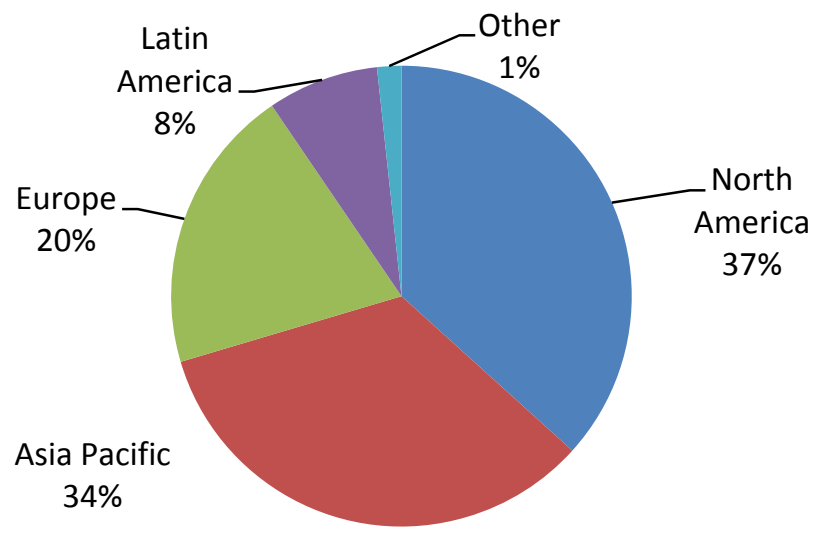

Figure 2. Global futures and options volume by region in 2012 source: FIA Annual Volume Survey 2013.

According to the BIC the over-the-counter derivatives market continued to expand in the second half of 2013. The net amount of outstanding OTC derivatives contracts, which determines contractual payments and is an indicator of activity in OTC derivatives markets, totalled 710 trillion USD at end-December 2013 (BIC, 2014). This compares with 693 trillion USD at end-June 2013 and 633 trillion USD at end-2012. Adjusted for exchange rate movements, notional amounts at end-2013 were about $1 \%$ higher than at end-June 2013 and $13 \%$ higher than at end of 2012. But the market value of derivative contracts declined, based on market prices at end of December 2013. The gross market value of all contracts amounted to 19 trillion USD at end of December 2013. This is down from 20 trillion USD at end of June 2013 and 25 trillion USD at end of 2012 (BIC, 2013). 
The decrease during recent half-year in gross market value of derivatives was mainly due to the decrease in interest rate swaps and options

In the Quarterly review in September 2014 BIC stated that amounts outstanding in futures and options traded on organized markets increased from 24076.8 billion USD to 29095.6 billion USD in futures markets and accordingly from 30037.6 billion USD to 44302.9 billion USD in options markets. The conclusion can be done that both OTC and exchange traded markets of derivatives are growing.

A few years have passed after recession in the United States of America, but the global economy still feels some consequences and tries to solve the problems. Some authors claim (Kolb et al., 2010) that derivatives have contributed to financial disasters from the bankruptcy of Lehman Brothers in 2008 to J.P. Morgan's trading losses in London in 2012 (Hammoudeha \& McAleer, 2013). The major source of problems was the private nature of derivatives contracting with limited public information and the difficulties of understanding the nature and level of taken risks.

According to Marthinsen (2010) problems with the use of derivatives have started in 1993 (Table 1).

Table 1. Major Derivative Scandals in Financial Markets

\begin{tabular}{|c|c|c|c|}
\hline Year & Company & $\begin{array}{c}\text { Loss } \\
\text { (Billions) }\end{array}$ & Financial instruments \\
\hline 1993 & $\begin{array}{l}\text { Metallgesellschaft Refining and } \\
\text { Marketing (MGRM) }\end{array}$ & 1.3 USD & U.S. oil and gas futures contracts \\
\hline 1995 & Barings Bank (Barings) & 1.2 USD & $\begin{array}{l}\text { Japanese equity and government bond } \\
\text { futures contracts }\end{array}$ \\
\hline 1998 & $\begin{array}{l}\text { Long-Term Capital } \\
\text { Management (LTCM) }\end{array}$ & 4.5 USD & Leveraged global spread trades \\
\hline 2006 & Amaranth Advisors (Amaranth) & 6.4 USD & U.S. natural gas futures contracts \\
\hline 2008 & Societe Generale (SocGen) & 7.2 USD & European index futures \\
\hline
\end{tabular}

Source: Marthinsen (2010).

The main reasons for problems associated with derivatives were the highly leveraged, speculative positions (Marthinsen, 2010). In some situations risks from derivatives originate with the customer. Financial derivatives allow the institution to break up risks and distribute them around the financial system using secondary markets while creating various kinds of contracts. Thus, many risks associated with derivatives are actually created by the dealers' customers or by their customers' customers (Hentshel et al., 2009).

Risks are similar to those faced in traditional markets, such as price, interest rate, liquidity, credit risk and so on. Many of the risks are the same for derivatives on all types of underlying interests, although some special risks may apply only to derivative securities of particular types of underlying asset. New types of derivatives are especially risky because of their novelty, complexity and users' inexperience.

Some authors that studied the risk of derivative securities emphasize different kinds of risk characteristic for derivative contracts. Market and credit risks are pointed out as main ones by Gangahar (2000) and Bartram et al. (2011). Besides these two, types 
of risk mentioned in other sources point to a third risk - systemic risk - as the combination of market and credit risks (Munter \& Rotcliffe, 2001). Sill (1997) points out credit risk, pricing risk and liquidity risk.

According to Options Clearing Corporation (OCC) important risks include strategic, reputation, price, foreign exchange, liquidity, interest rate, credit, transaction and compliance (Hull, 2000). Reinstein \& Lauder (2001) mark out market, credit, liquidity, legal and operational. Friedentag (2000) uses the following classification: market risk, credit risk, operational risk, legal risk and system risk. A similar classification is followed by Krawiec (1998). In the paper of Henstel \& Smith (1995) agency risk is recognized as quite important.

The above mentioned risks are the same for other traditional lending and investment activities. Yet because over the counter derivatives are customized to meet the needs of a particular counterparty, these risks are often assembled in new and unexpected ways, sometimes leading to unforeseen losses (Krawiec, 1998). Exotic derivatives, for example such as chooser or barrier options have features that make them more difficult to understand then simple derivatives. Some derivatives may end in big losses because of small changes in the value of the underlying asset. Derivatives that are involved into other securities are quite difficult to identify, so the risk of such contracts is bigger because of the possibility of incorrect evaluation.

Market risk of derivative contract is the exposure to the possibility of financial loss resulting from any unfavourable movement in interest rates, equity or commodity prices, and currency rates. That is adverse movements in the price of a financial asset or commodity. Many financial institutions use the term market risk interchangeably with price risk. This risk arises to earnings or capital because of the changes in the value of portfolios of financial instruments (Huang et al. 2001). Estimating the market value of derivative can be difficult because of a variety of existing factors such as time until expiration, interest rates, changes of underlying asset price, dividends and other influence it. In the case of over the counter contracts the lack of centralised market ads additional difficulties (Friedentag, 2000).

Another risk in the use of derivatives regardless their type and able to cause enormous loses is liquidity risk. Liquidity risk refers to the ease with which the contract can be traded. This risk is not specific to derivative contracts, but it can play a significant role in any financial market during periods of significant changes in economics or high volatility. This risk can greatly impact the credit and market risk of a security or portfolio (Krawiec 1998). When securities become illiquid, it is more difficult to determine their market value. Firms trying to sell illiquid securities may find that the real market value of their portfolios and securities differs substantially from the calculated values (Sill, 1997). It is clear that liquidity risk of the derivative contracts is closely related with their market risk and also depends on market conditions and counterparty. Investors who plan to sell a derivative before maturity need to consider at least two major points: how easy or difficult will it be to sell it before maturity, and how much will it cost. In some cases the fees or penalties for selling may occur (Qiu \& Yu, 2012).

Users of all derivative products face two types of liquidity risk: funding liquidity risk and market liquidity risk. Funding liquidity risk refers to situations in which a market participant will be unable to meet its payment obligations on the settlement date or in 
the event of a margin call (Krawiec, 1998). Market liquidity risk refers to situations when a market participant may not be able to exit or offset positions quickly, and in sufficient quantities, at a reasonable price. This inability may be due to inadequate market depth, market disruption, or other reasons. Some exotic product markets lack depth because of a small number of market participants (Hull, 2000). The over the counter market is considered significantly less liquid than the exchange-traded market. The standardisation of exchange-traded contracts leads to greater liquidity. The use of clearinghouses, the anonymous nature of exchange trading, and the relatively small contract size all lead to a highly liquid exchange-traded derivatives market that is different from the OTC market (Krawiec, 1998). In the OTC markets, the decision of only a few major market makers to reduce participation in specific markets may decrease market liquidity. The liquidity of certain markets may depend on the activeness of large institutional investors. If these do not trade actively, liquidity in the market will decline (Sill, 1997). Over the counter contracts can be difficult to transfer because of their customized nature and relatively large contract size.

Credit risk occurs in all transactions traded in the market. It is a significant element in the array of risks facing the derivatives dealer and the derivatives end-user. This risk implies that one party may default on the contract. According to Friedentag (2000) credit risk is the exposure to the possibility of financial loss resulting from the other party's failure to meet its financial obligations. Credit risk arises from all activities in which success depends on counterparty, issuer, or borrower performance. Credit risk in derivatives changes throughout the duration of the contract as the variables of the underlying contract change. The credit risk character of exchange-traded and over the counter derivatives differ sharply. Credit risk is not much of a problem for derivatives traded on organised exchanges, since these exchanges are designed in such a way that their contracts are almost always honoured (Sill, 1997). Counterparty credit risk is transformed into a much lower risk of failure of the clearing organisation itself. Credit risk is a bigger problem in the over the counter market, where two parties conclude a derivative contract specific to their needs. Managing credit risk can be difficult because the credit worthiness of the other party can change rapidly and there can be only limited control over that (Arora et al., 2013).

The risk that counterparty in a derivatives contract will not satisfy its obligations under the contract, for example, by failing to supply goods in a futures contract is counterparty risk. This could cause major problems to a counterparty that would be left suddenly without a derivatives contract and no longer receiving payments under the contract. The fact that many derivatives trades are done orally with little or no accompanying documentation complicates the matter even more. Besides the OTC market is largely unregulated so exchange-traded derivatives have much lower counterparty risk, because the counterparty in each transaction is the exchange clearinghouse rather than a single OTC trader (Arora et al., 2013).

Insufficient or unfit documentation, insufficient capacity or authority of counterparty, illegality of a contract, can cause another type of risks. Legal risk presents in all financial activities, including traditional lending and trading activities, and it takes on added importance in the context of derivatives transactions because they are relatively novel and complex (Krawiec, 1998). OTC derivatives, in particular, are subject 
to legal risk due to the lack of exchange standardisation of contracts and regulatory review of their terms and conditions to which exchange-traded derivatives are subjected to (Krawiec, 1998; Friedentag 2000). A major legal risk faced by participants in any derivatives market is the risk that a contract will be unenforceable because an entire class of contracts is declared illegal or unenforceable (Krawiec, 1998). Legal risk can also arise from the possibility that counterparty will be declared legally incapable of entering into a derivative contract.

Generally transaction risk is the risk to earnings or capital arising from problems with service or product delivery. This risk is a function of internal controls, information systems, employee integrity, and operating processes. Transaction risk exists in all products and services. Sill (1997), Krawiec (1998) and Friedentag (2000) named such a risk as operational risk. According to these authors operational risk is the risk of loss occurring as a result of inadequate systems and controls, human errors or management failure (Krawiec, 1998). Operational failure can increase other types of risks discussed. For example, the failure to monitor and review trading activity to ensure that counterparty credit limits or risk exposures are not exceeded can increase credit and market risk, respectively (Krawiec, 1998; Mitra, 2013).

Interconnection risk, also known as systemic risk, is the danger that difficulties experienced by any single player in the derivatives market could trigger a chain reaction that might ultimately affect the financial system. Interdependence in the market created by the large number of derivatives contracts determine that the default of one party can have far-reaching implications for the creditworthiness of its counterparties. This can lead to systemic risk. Systemic risk is clearly affected by the size of the counterparty: the larger the counterparty, the greater effect its default causes on the market as a whole.

Risk concerned with derivative securities may be classified according to a number of factors, for example, trading of securities in general, the state of the economy, the supply and demand factors in the derivative and other financial or commodities markets, the factors affecting the values of the underlying interests, market volatility, liquidity and efficiency, various factors affecting the pricing of particular derivatives, the quality or operations of the derivatives markets at any particular time, number of intermediaries in the markets, existence of rules of regulation and so on.

Factors affecting the rise of derivatives risk may be divided according to:

- specific characteristics of derivative (type of derivative),

- trading conditions in the markets (underlying asset, type of the market, time to expiration),

- complexity of the contract (covered position, naked position, plain vanilla derivative or complex one),

- position taken in the contract (holder of the contract, writer of the contract, intermediary).

Identifying the risks associated with derivatives determines the design, operation and evaluation of an effective risk management system. The basic kinds of risks associated with derivatives are not new and different from those associated with traditional financial instruments. But some specific risk can occur especially in the case of exotic derivatives. 


\section{CONCLUSIONS}

It can be concluded that, despite of failures in markets associated with derivative securities, the use of this financial means is not going to stop. Global financial markets will need and will continue to develop new financial innovations necessary to improve risk management. Nowadays derivative contracts are not only the hedging tool; they are important arbitrage and speculation tools, too. Financial derivatives are important tools that can help organisations to meet their specific risk-management objectives.

Despite their purpose to hedge from risks, derivative contracts are risky as every financial activity in the market. According to the analysed literature, different types of risk exist. The analysis led to the conclusion, that main risks actual to derivatives contracts and their traders are market risk, liquidity risk, credit and counterparty risk, legal risk and transactions risk. Pricing risk and systemic risk is also quite important. The analysis showed that market risk is the most important kind of risk that has close connection with remaining risks and in many situations influences the rise of remaining risks. Market risk occurs when the investor is wrong about the market, and counterparty risk occurs when he is right about the market direction, but wrong about whom to do business with. Some types of risk are more relevant for hedgers, some of them are more relevant for speculators. Some risks are common for all types of derivatives.

Risk of derivative contracts can be related with the following factors: main characteristics of contracts, trading conditions; position taken in the contract, complexity of the contract.

Financial derivatives are important tools that can help organisations meet their specific risk-management objectives. It is important that the user understands the functions and the necessary safety precautions before using derivatives in his risk management strategy. When used wisely, financial derivatives can increase shareholder value by providing means to better control a firm's risk exposures and cash flows.

Further research on the topic will be focused on risks influencing separate derivative securities, because the research showed that it is quite difficult to analyse all derivative securities together.

\section{REFERENCES}

Arora, N., Gandhi, P., \& Longstaff, F.A. (2013). Counterparty credit risk and the credit default swap market. Journal of Financial Economics, 103, 280-293.

Bank for International Settlements. Derivative statistics. Retrieved on October 20, 2014, from <http://www.bis.org/statistics/derstats.htm>.

Bartram, S. M., Brown, G. W., Conrad, J. (2011). The Effects of Derivatives on Firm Risk and Value. Journal of Financial and Quantitative Analysis, 46(04), 967-999 DOI: http://dx.doi.org/10.1017/S0022109011000275.

Benhamou, E. (2007). Global derivatives: Products, Theory And Practice. USA: World Scientific Publishing Company.

Carruthers, B.G. (2013). Diverging derivatives: Law, governance and modern financial markets, Journal of Comparative Economics 41: 386-400. http://dx.doi.org/10.1016/j.jce.2013.03.010.

Chisholm, A.M. (2004). Derivatives Demystified: A Step-by-Step Guide to Forwards, Futures, Swaps and Options. Hoboken, NJ: John Wiley \& Sons. 
Culp, Ch.L. (2004). Risk Transfer : Derivatives in Theory and Practice. USA: John Wiley \& Sons.

Cusatis, P.J., \& Thomas, M.R. (2005). Hedging Instruments and Risk Management. USA: The McGraw-Hill.

Deutsche Borse Group. The Global Derivatives Market: A Blueprint for Market Safety and Integrity. White paper Retrieved on October 20, 2014, from <http://deutscheboerse.com/dbg/ dispatch/en/binary/gdb_content_pool/imported_files/public_files/10_downloads/80_misc/ whitepaper_derivatives2.pdf $>$.

FIA Annual Volume Survey (2013). Retrieved on October 20, 2014, from <http://www.futuresindustry.org/downloads/FIA_Annual_Volume_Survey_2013.pdf>.

Friedentag, H.C. (2000).Stocks for options trading: low-risk, low-stress strategies for selling stock options profitably. USA: CRC Press LLC.

Gangahar, A. (2000). Derivatives: friend or foe? Global Investor, 17-21.

Hammoudeha, Sh., McAleer, M. (2013). Risk management and financial derivatives: An overview. North American Journal of Economics and Finance, 25, 109-115.

Hentschel, L., \& Smith, C. W. (2009). Risks in derivatives markets. Working paper, The Wharton School, University of Pennsylvania.

Hull, J.C. (2000). Options, futures and other derivatives. USA: Prentice Hall, $4^{\text {th }}$ edition.

Huang, T., Srivastava, V., \& Raatz S. (2001). Portfolio optimisation with options in the foreign exchange market. Derivatives Use, Trading \& Regulation, 7(1), 55-72.

Hung, M.-W., Lin, B.-H., Huang, Y.-C., \& Chou, J.-H. (2011). Determinants of futures contract success: Empirical examinations for the Asian futures markets. International Review of Economics and Finance, 20: 452-458. doi: 10.1016/j.iref.2010.11.015

Kolb, R.W., \& Overdahl, J.A., (Eds.). (2010). Financial Derivatives: Pricing and Risk Management. Hoboken, NJ: John Wiley \& Sons.

Kotze, A. A. (2011). Foreign Exchange Derivatives: Effective Theoretical and Practical Techniques for Trading, Hedging and Managing FX Derivatives. Financial Chaos Theory Pty. Ltd.

Krawiec, K.D. (1998). More than just "new financial bingo": A risk-based approach to understanding derivatives. Journal of Corporation Law, 23, 1-63.

Marthinsen, J.E. (2010). Derivative Scandals and Disasters (chapter 23). In R.W. Kolb, \& J.A. Overdahl (Eds.), Financial Derivatives: Pricing and Risk Management (pp. 313-332). Hoboken, NJ: John Wiley \& Sons.

Miffre, J., \& Brooks, C. (2013). Do long-short speculators destabilize commodity futures markets? International Review of Financial Analysis, 30, 230-240. http://dx.doi.org/10.1016/j.irfa. 2013.09.002.

Mitra, S. (2013). Operational risk of option hedging. Economic Modelling, 33, 194-203.

Munter, P., \& Rotcliffe, Th.A. (2001). Auditing derivatives and securities. The CPA Journal, 71, 3744.

Pineda, S., \& Conejo, A.J. (2012). Managing the financial risks of electricity producers using options. Energy Economics, 34, 2216-2227.

Qiu, J., \& Yu, F. (2012). Endogenous liquidity in credit derivatives Journal of Financial Economics, $103,611-631$.

Rangarajan, K.S. (2012). [online] Derivatives in Financial Market Development. Stern School of Business, New York University Retrieved on October 20, 2014, from < http://www.theigc.org/wp-content/uploads/2014/09/Sundaram-2013-Working-Paper.pdf>. 
Reinstein, A., \& Lander, G.H. (2000). Are the new rules relating to disclosures of derivative financial instruments. International Advances in Economic Research, 6, 95-100.

Scalcione, R. (2011). The Derivatives Revolution. A Trapped Innovation and a Blueprint for Regulatory Reform. Netherlands: Kluwer Law International.

Sill, K. (1997). The economic benefits and risks of derivative securities. Business Review Jan/Feb, 15-27.

\section{Author}

\section{Raimonda Martinkutè-Kaulienè}

Doctor of Social Sciences and Economics (Vilnius Gediminas Technical University, Lithuania); Associate Professor at the Department of Finance Engineering at Vilnius Gediminas Technical University (Lithuania). Her research interests include risk management and derivative securities.

\section{Correspondence to:}

Assoc. Prof. Raimonda Martinkutè-Kaulienè, PhD

Vilnius Gediminas Technical University

Faculty of Business Management

Sauletekio av. 11

10223 Vilnius, Lithuania

raimonda.martinkute@vgtu.It

\section{Copyright and License}

This article is published under the terms of the Creative Commons Attribution - NonCommercial - NoDerivs (CC BY-NC-ND 3.0) License http://creativecommons.org/licenses/by-nc-nd/3.0/ 
